\title{
Resistance of Scots pine (Pinus sylvestris L.) wood modified with functionalized commercial silicone emulsions against subterranean termites
}

\author{
Shyamal C. Ghosh • Brenton C. Peters • \\ Chris J. Fitzgerald $\cdot$ Holger Militz $\cdot$ Carsten Mai
}

Received: 9 August 2010/Published online: 5 February 2012

(C) The Author(s) 2012. This article is published with open access at Springerlink.com

\begin{abstract}
Scots pine (Pinus sylvestris L.) sapwood was treated with quat-silicone micro-emulsion $(<40 \mathrm{~nm})$, amino-silicone macro-emulsion $(110 \mathrm{~nm})$, alkyl-modified silicone macro-emulsion $(740 \mathrm{~nm})$ and solutions of inorganic water glass. Three treatment concentrations of 5, 15 and $30 \%$ (w/w) were used for the impregnation of the test specimens. Termite resistance was assessed following a 16-week field trial conducted in northern Queensland, Australia. Two different field sites were chosen for exposure to feeding by Coptotermes acinaciformis (Froggatt) and Mastotermes darwiniensis (Froggatt). Following exposure, the test and feeder specimens were inspected and assessed for termite damage using a visual rating system (from 10 sound to 0 completely destroyed) and individual mass losses. The specimens treated with quat- and amino-silicone emulsions resisted damage by both termite species, even at less than $15 \%$ weight percent gains (WPGs). Alkyl-modified silicone macroemulsion and water glass treatment induced somewhat less resistance to termite damage, but imparted protection at higher WPGs.
\end{abstract}

\section{Introduction}

Tests for termite resistance of wood can be conducted under both laboratory and field conditions to compare the susceptibility of materials or to examine the performance of protective chemicals under test (Howick and Creffield 1983). Laboratory test methods are usually adopted for the termiticide development research, while the field tests can simulate the real in-service performance scenario

S. C. Ghosh · H. Militz · C. Mai $(\bowtie)$

Wood Biology and Wood Products, Burckhardt Institute, Georg-August-University Göttingen,

Büsgenweg 4, 37077 Göttingen, Germany

e-mail: cmai@gwdg.de

B. C. Peters · C. J. Fitzgerald

Department of Primary Industries and Fisheries, 80 Meiers Rd, Indooroopilly, QLD 4068, Australia 
of treated material (Preston et al. 1986). Several methods to protect wooden structures from termite damage include the use of naturally durable wood species, preservative treatments and engineered wood products with enhanced insect and decay resistance (Grace 2003). The reduced availability of naturally durable wood species, however, is increasing the dependence on the use of fast-grown non-durable wood for construction. The protection of structures made of non-durable wood may require the application of broad-spectrum insecticides. The use of various organochlorine insecticides as chemical barriers to termites was a common practice until environmental concerns restricted their widespread applications (French 1991). Present practices using insecticides as chemical preservatives are broadly categorized into three toxic levels, such as repellent, non-repellent causing rapid mortality and non-repellent with a delayed action (Su et al. 1982; Woodrow and Grace 2008). New safer treatment procedures in wood and soil are being constantly developed for effective termite control, for example, physical barriers using basaltic particles (Tamashiro et al. 1987, 1991) and stainless steel mesh (Lenz and Runko 1994). These have been developed as substitutes for soil treatment with chemicals. Biological control measures have also been reported using natural parasites or predators to reduce termite population, but show limited field efficacy (Woodrow and Grace 2008).

A number of wood modification techniques have already been commercialized (Hill 2006) substituting the use of toxic chemicals for wood protection. Acetylation up to a WPG of 20-22\% has been found to impart resistance to termite damage (Imamura and Nishimoto 1986; Westin et al. 2004). Furfurylated wood treated with medium (48\% WPG) and high concentration (92\% WPG) of furfuryl alcohol strongly resisted drywood and subterranean termite damage (Hadi et al. 2005). Furthermore, wood modified with 1,3-dimethylol-4,5-dihydroxy ethylene urea (DMDHEU) has recently been found to be resistant to Coptotermes acinaciformis at 1.3 and $2.1 \mathrm{~mol} \mathrm{1}^{-1}$, but not to Mastotermes darwiniensis (Militz et al. 2008).

Treatment of solid wood with amino- and ammonium-functionalised silicones was shown to inhibit colonization by staining and mould fungi (Ghosh et al. 2009) and fungal decay (Weigenand et al. 2008; Ghosh et al. 2008), and to impart moderate dimensional stability and water repellence (Weigenand et al. 2007; Ghosh et al. 2009). However, alkyl-functionalised silicones imparted considerably lower resistance against fungi than the nitrogen-containing silicones. These findings are promising with regard to the development of new wood protection processes, but the effect of the sole treatment with silicone emulsions on the termite resistance has not yet been shown.

Water glasses are potassium or sodium silicates or solutions typically composed of 2-4 mol silicate and $1 \mathrm{~mol}$ alkali oxide. They are soluble in water and form a colloidal clear, heavily alkaline solution $(>12 \mathrm{pH})$ at elevated temperatures and pressures (Römpp 1995; Mai and Militz 2004). Wood treated with water glass has also been studied to improve the fungal decay (Furuno et al. 1991, 1992, 1993; Matthes et al. 2002) and termite resistance (Furuno and Imamura 1998). In this study, wood treatment with commercial silicone emulsions with different functional groups and particle sizes as well as water glass was tested in order to assess the resistance against $C$. acinaciformis (Froggatt) and $M$. darwiniensis (Froggatt) in the 
field in northern Queensland, Australia, as previously described (Peters and Fitzgerald 2004; Peters et al. 2006; Militz et al. 2008).

\section{Experimental}

Chemicals and treatment of wood

Scots pine (Pinus sylvestris L.) sapwood specimens $(25 \times 75 \times 190 \mathrm{~mm}$ [longitudinal]) were treated with three commercial silicone emulsions (Table 1, Momentive GmbH, Leverkusen, Germany) and aqueous silicate solution ("water glass," Betol $^{\circledR}$ 39T3, Woellner GmbH, Ludwigshafen, Germany), and the weight percent gain (WPG) was calculated as previously described by Donath et al. (2004). Silicone and silicate concentrations of 5, 15 and $30 \%(\mathrm{w} / \mathrm{w})$ were adjusted by diluting the stock solutions with demineralised water. Eight test specimens were treated with each chemical and treatment concentration. Untreated Radiata pine (Pinus radiata D. Don) sapwood $(35 \times 75 \times 190 \mathrm{~mm}$ [longitudinal] $)$ served as feeder specimens.

Termites

The test specimens and feeder specimens were exposed to $C$. acinaciformis and M. darwiniensis at two different sites near Townsville, Australia. C. acinaciformis occurs in mounds on a private property near Black River $\left(19^{\circ} 13^{\prime} \mathrm{S}, 146^{\circ} 47^{\prime} \mathrm{E}\right)$, just north of Townsville. M. darwiniensis, the most destructive termite in Australia, occurs on a private property at Rowes Bay $\left(19^{\circ} 13^{\prime} \mathrm{S}, 146^{\circ} 47^{\prime} \mathrm{E}\right)$, Townsville.

Field assay

Both treated and untreated test specimens (total 104) were exposed to termite feeding according to the Australian Wood Preservation Committee (AWPC) (2007). The specimens were weighed and assigned to 26 test containers ( 61 plastic food

Table 1 List of chemicals used for the treatment of wood

\begin{tabular}{llllll}
\hline Formulation & $\begin{array}{l}\text { Emulsion } \\
\text { particle } \\
(\mathrm{nm})\end{array}$ & $\begin{array}{l}\text { Silicone } \\
\text { content } \\
(\%)\end{array}$ & $\begin{array}{l}\text { Solid } \\
\text { content } \\
(\%)\end{array}$ & $\begin{array}{l}\mathrm{N} \text { content } \\
\left(\mathrm{mmol} \mathrm{g}^{-1}\right)\end{array}$ & $\begin{array}{l}\text { Structure of } \\
\text { functional } \\
\text { group }\end{array}$ \\
\hline $\begin{array}{l}\text { Quat-silicone micro-emulsion } \\
\text { (QuatSiMiE) }\end{array}$ & $<40$ & 35 & 47 & 0.25 & $\begin{array}{l}\text { Quaternary ammonium, } \\
\mathrm{R}^{1}-\mathrm{N}^{+}\left(\mathrm{CH}_{3}\right)_{2}-\mathrm{R}^{2}\end{array}$ \\
$\begin{array}{l}\text { Amino-silicone macro- } \\
\text { emulsion (AminoSiMaE) }\end{array}$ & 110 & 35 & 38 & 0.25 & $\begin{array}{l}\mathrm{Amino}^{2}, \\
\left(\mathrm{CH}_{2}\right)_{3}-\mathrm{NH}_{2}\end{array}$ \\
$\begin{array}{c}\text { Alkyl-modified silicone } \\
\text { macro-emulsion } \\
\text { (AlkylSiMaE) }\end{array}$ & 740 & 35 & 38 & 0 & $\begin{array}{l}\mathrm{Alkyl-modified,} \\
\left(-\mathrm{CH}_{12}-\mathrm{C}_{14}\right)\end{array}$ \\
\begin{tabular}{l} 
Water glass \\
\hline
\end{tabular} & - & - & 36 & 0 & - \\
\hline
\end{tabular}


containers, $90 \times 210 \times 310 \mathrm{~mm}$ long). In each test container, there were four test specimens and five feeder specimens. The test specimens in each test container were selected at random from the thirteen treatments (three concentrations of four treatments and untreated control). Two control containers were used with seven feeder specimens in each. Thirteen test containers and one control container were used for each species of termite.

The test containers with test specimens as well as one container with control specimens were attached to a $C$. acinaciformis mound, via hollow concrete bricks established adjacent to one another along a section of a trench. Radiata pine feeder stakes were driven into the ground within the gaps of the bricks to facilitate the movement of termites from the ground to the test specimens. Test containers were exposed to M. darwiniensis in the same way as described earlier (Peters et al. 2006). Each test container was covered with insulating material secured with soil. The trials were installed on 16th June 2008, and following exposure for 16 weeks (Australasian Wood Preservation Committee 2007), the specimens were inspected, visually assessed and oven-dried to calculate mass losses. The visual ranking of the samples were done as: sound samples with sign of no damage-10, signs of light damage and surface nibbles-9, moderate damage and noticeable surface penetration-7, heavy damage-4 and completely destroyed-0 (American WoodPreservers' Association 2007).

\section{Results and discussion}

Termite activity was considered strong as evident from the mass loss data for feeder specimens at both sites. The average mass loss of the feeder specimens damaged by $C$. acinaciformis was $42.5 \%$. The specimens treated with QuatSiMiE and AminoSiMaE showed strong resistance to $C$. acinaciformis damage at all treatment concentrations, with no visible sign of feeding by the termites (Table 2). Test specimens treated with low concentration $(5 \%)$ of AlkylSiMaE and water glass sustained minor mass losses (slightly above 5\%) due to the damage by $C$. acinaciformis. However, this was not observed at moderate (15\%) and high $(30 \%)$ treatment concentrations, that is, WPG (Table 2).

The average mass loss of the feeder specimens exposed to $M$. darwiniensis was 45.1\%. Similar to the results of $C$. acinaciformis, test specimens treated with QuatSiMiE and AminoSiMaE showed strong resistance to the damage by M. darwiniensis (Table 3). AlkylSiMaE-treated test specimens showed a low degree of termite decay and corresponding mass loss at low (5\%) and moderate (15\%) treatment concentration, but no damage was observed at higher WPG attained by $30 \%$ treatment concentration. Water glass-treated test specimens were damaged by $M$. darwiniensis at low WPG (5\% treatment concentration) only.

Mass loss results of both test termites were found to be in agreement with the visual rating system for both $C$. acinaciformis (Table 2) and M. darwiniensis (Table 3) done according to American Wood-Preservers' Association (AWPA) (2007). Both the QuatSiMiE and AminoSiMaE have been found to be strongly resistant to termite damage even at low WPGs. The occasional nibble by M. darwiniensis on test 
Table 2 Oven-dry mass, weight percent gain (WPG) and mass loss due to $C$. acinaciformis damage $(n=8$, mean values \pm standard deviation)

\begin{tabular}{llllr}
\hline Treatment & $\begin{array}{l}\text { Average oven-dry } \\
\text { weight of test } \\
\text { specimen }(\mathrm{g})\end{array}$ & WPG $(\%)$ & $\begin{array}{l}\text { Mass loss due to } \\
\text { termite damage }(\%)\end{array}$ & $\begin{array}{l}\text { Average rank of } \\
\text { termite damage }\end{array}$ \\
\hline 5\% QuatSiMiE & $180.9( \pm 7.1)$ & $14.4( \pm 3.1)$ & 0 & $10.0( \pm 0.0)$ \\
$5 \%$ AminoSiMaE & $170.9( \pm 6.6)$ & $10.3( \pm 0.5)$ & 0 & $10.0( \pm 0.0)$ \\
$5 \%$ AlkylSiMaE & $173.7( \pm 4.9)$ & $11.7( \pm 3.2)$ & $5.1( \pm 2.2)$ & $9.3( \pm 0.5)$ \\
$5 \%$ Water glass & $199.7( \pm 3.2)$ & $7.2( \pm 0.1)$ & $6.1( \pm 4.3)$ & $7.8( \pm 1.5)$ \\
$15 \%$ QuatSiMiE & $202.0( \pm 8.2)$ & $36.9( \pm 2.7)$ & 0 & $10.0( \pm 0.0)$ \\
$15 \%$ AminoSiMaE & $198.6( \pm 2.4)$ & $29.1( \pm 1.9)$ & 0 & $10.0( \pm 0.0)$ \\
15\% AlkylSiMaE & $192.4( \pm 7.2)$ & $27.8( \pm 4.3)$ & 0 & $10.0( \pm 0.0)$ \\
$15 \%$ Water glass & $223.6( \pm 5.5)$ & $21.4( \pm 2.2)$ & 0 & $10.0( \pm 0.0)$ \\
$30 \%$ QuatSiMiE & $231.0( \pm 8.4)$ & $34.3( \pm 4.8)$ & 0 & $10.0( \pm 0.0)$ \\
$30 \%$ AminoSiMaE & $236.0( \pm 24.6)$ & $35.3( \pm 15.1)$ & 0 & $10.0( \pm 0.0)$ \\
$30 \%$ AlkylSiMaE & $249.5( \pm 3.8)$ & $46.4( \pm 2.9)$ & 0 & $10.0( \pm 0.0)$ \\
$30 \%$ Water glass & $240.3( \pm 3.8)$ & $28.5( \pm 2.9)$ & $0.3( \pm 0.5)$ & $10.0( \pm 0.0)$ \\
Untreated & $192.6( \pm 12.1)$ & - & $31.8( \pm 9.4)$ & $4.0( \pm 0.0)$ \\
\hline
\end{tabular}

specimens treated with 15 and $30 \%$ concentrations of AminoSiMaE resulted in mass loss less than $1 \%$. A single termite nibble was observed on only one test specimen of AminoSiMaE treatment (both 15 and 30\% treatment concentration).

The untreated Scots pine wood specimens were heavily damaged by both termite species. However, only surface nibbles were observed in case of 5\% AlkylSiMaEtreated wood by $C$. acinaciformis, and several holes were created in one test specimen of 5\% water glass treatment. The foraging of $M$. darwiniensis in 5\% AlkylSiMaE and water glass test specimens were found to be restricted to the surface only. According to the Australian Wood Preservation Committee (2007) protocols, both of these treatments could be considered effective in preventing termite damage in the test specimens. Nevertheless, wood treated with AlkylSiMaE and water glass was also resistant to termite damage at 15 and $30 \%$ treatment concentration. The performance of silicon-based compounds to protect wood from termite damage is still in the early stages and requires further studies to explain the termite resistance mechanism of such treatments.

Various grain crops with high silica content have been reported to be resistant to boring insects, for example, stem borers, damage in ryegrass (Moore 1984), rice (Tayabi and Azizi 1984) and corn (Horng and Chu 1990). Similarly, the natural durability of high silica content wood species (Amos 1952) as well as their resistance against wood boring organisms, for example, marine borers (van Iterson 1933), could be a basis to explain the termite resistance of silicone- and water glasstreated wood. Japanese black pine (Pinus thumbergii Parl.) treated with low molecular weight silicic acid exhibited increased termite resistance; the combination with boric acid improved the performance against termites (Yamaguchi 2003). Kartal et al. (2007) reported reduced termite damage (less than $2 \%$ mass loss) in 
Table 3 Oven-dry mass, weight percent gain (WPG) and mass loss due to $M$. darwiniensis damage $(n=8$, mean values $\pm \mathrm{SD})$

\begin{tabular}{llclr}
\hline Treatment & $\begin{array}{l}\text { Average oven-dry } \\
\text { weight of test } \\
\text { specimen }(\mathrm{g})\end{array}$ & WPG $(\%)$ & $\begin{array}{l}\text { Mass loss due to } \\
\text { termite damage }(\%)\end{array}$ & $\begin{array}{l}\text { Average rank of } \\
\text { termite damage }\end{array}$ \\
\hline 5\% QuatSiMiE & $186.4( \pm 12.2)$ & $19.0( \pm 6.4)$ & 0 & $10.0( \pm 0.0)$ \\
$5 \%$ AminoSiMaE & $171.6( \pm 5.0)$ & $9.8( \pm 0.9)$ & 0 & $10.0( \pm 0.0)$ \\
$5 \%$ AlkylSiMaE & $176.8( \pm 8.8)$ & $11.9( \pm 2.5)$ & $3.3( \pm 3.3)$ & $9.5( \pm 0.6)$ \\
$5 \%$ Water glass & $199.8( \pm 3.9)$ & $7.1( \pm 0.1)$ & $0.8( \pm 1.1)$ & $10.0( \pm 0.0)$ \\
$15 \%$ QuatSiMiE & $206.9( \pm 13.2)$ & $33.0( \pm 8.7)$ & 0 & $10.0( \pm 0.0)$ \\
$15 \%$ AminoSiMaE & $199.4( \pm 6.6)$ & $29.6( \pm 1.9)$ & $0.3( \pm 0.6)$ & $9.8( \pm 0.5)$ \\
$15 \%$ AlkylSiMaE & $192.7( \pm 7.2)$ & $27.1( \pm 3.9)$ & $1.0( \pm 1.9)$ & $9.8( \pm 0.5)$ \\
$15 \%$ Water glass & $225.5( \pm 4.3)$ & $22.0( \pm 1.2)$ & 0 & $10.0( \pm 0.0)$ \\
$30 \%$ QuatSiMiE & $239.5( \pm 18.2)$ & $39.4( \pm 10.7)$ & 0 & $10.0( \pm 0.0)$ \\
$30 \%$ AminoSiMaE & $224.8( \pm 13.4)$ & $29.0( \pm 6.9)$ & $0.3( \pm 0.5)$ & $10.0( \pm 0.0)$ \\
$30 \%$ AlkylSiMaE & $249.8( \pm 5.9)$ & $47.0( \pm 2.8)$ & 0 & $10.0( \pm 0.0)$ \\
$30 \%$ Water glass & $250.1( \pm 11.6)$ & $35.3( \pm 7.3)$ & 0 & $10.0( \pm 0.0)$ \\
Untreated & $188.9( \pm 8.2)$ & - & $35.7( \pm 11.9)$ & $6.3( \pm 1.5)$ \\
\hline
\end{tabular}

wood treated with combination of various silane formulations and borate, but advised for further research to understand the mechanism of resistance. Furuno and Imamura (1998) reported strongly reduced weight losses $(4.0,1.5,16.0 \%)$ caused by C. formosanus in wood samples treated with water glass in combination with boric acid, borax and potassium borate, respectively (weight loss of the control was $22.1 \%$ ). The weight losses of treated wood observed for the combination of boron compounds and water glass were lower than for the respective sole treatments with the boron compounds. Dual treatment with 5\% acetic acid and water glass clearly reduced the weight loss to $10.5 \%$ and increased the mortality of $C$. formosanus as compared with the untreated control (Furuno and Imamura 1998). This indicates that water glass alone has a protective effect on the resistance against termites, because acetic acid is not toxic or a repellent for termites, particularly when its $\mathrm{pH}$ value is neutralized by water glass.

The frequent use of quaternary ammonium compounds as wood preservatives has been reported by several authors (Preston et al. 1987; Matejuk et al. 2004; Pernak et al. 1998, 2004; Urbanik et al. 1997). Ghosh et al. (2008, 2009) have reported that treatment with QuatSiMiE and AminoSiMaE increased the resistance of wood to staining, mould as well as white and brown rot decay fungi, while the AlkylSiMaE did not show such performance. Several reasons have been considered for the higher fungal resistance imparted by the treatment. One might be an adverse effect of the amino or ammonium group on fungal physiology. Other reasons might be a closer association of the silicone molecules with the wood cell wall. This is assumed to be due to the formation of ionic bonds between the positively charged amino and quatgroups with negatively charged carboxylic groups in hemicelluloses. Amino groups can additionally bind covalently with the reducing end-groups of cell wall polysaccharides, that is, hemiacetal groups, resulting in a stronger interaction of 
amino-silicone with the wood cell wall. The modes of action of QuatSiMiE and AminoSiMaE toward fungi might also play a role with regard to the termite resistance of silicone treated wood. Although all silicone emulsions performed well in imparting termite resistance, pine wood treated with the alkyl-silicone AlkylSiMaE displayed somewhat lower durability than that treated with QuatSiMiE and AminoSiMaE.

\section{Conclusion}

Wood treated with quat- and amino-functional silicone emulsions showed resistance against subterranean termites even at less than 15\% WPG. AlkylSiMaE and the water glass treatment also reduced the damage by termites to a considerable extent at higher treatment concentrations.

Amino-functionalised silicone emulsions hold good potential to be used for treatment of wood exposed in hazard class 3 (European Standard EN 335-1, 2006), because they create a new material, which is resistant against basidiomycete decay fungi and fungal staining as well as termites.

Acknowledgments The authors acknowledge the contribution of Momentive Performance Materials $\mathrm{GmbH}$, Leverkusen, Germany, for supplying the chemicals and technical information.

Open Access This article is distributed under the terms of the Creative Commons Attribution License which permits any use, distribution, and reproduction in any medium, provided the original author(s) and the source are credited.

\section{References}

American Wood-Preservers' Association (2007) Standard test method for the evaluation of preservative treatments for lumber and timbers against subterranean termites in above-ground, protected applications (UC1 and UC2). In: Book of standards. pp 365-369. AWPA, Birmingham, Alabama, USA

Amos GL (1952) Silica in timbers. Bulletin no. 267. CSIRO, Melbourne

Australasian Wood Preservation Committee (2007) Protocols for assessment of wood preservatives. AWPC Publication, Melbourne, Australia. http://www.tpaa.com.au/files/AWPC\%20protocols.pdf. Accessed on 09/01/09

Donath S, Militz H, Mai C (2004) Wood modification with alkoxysilanes. Wood Sci Technol 35:555-566

European Standard EN 335-1 (2006) Durability of wood and wood-based products-Definition of use classes. European Committee for Standardization (CEN), Brussels

French JRJ (1991) Baiting techniques for control of Coptotermes species within existing buildings in Australia. USDA Forest Service Gen Tech Report, PSW 128, pp 46-50

Furuno T, Imamura Y (1998) Combinations of wood and silicate. 6. Biological resistance of woodmineral composites using water glass-boron compound system. Wood Sci Technol 32:161-170

Furuno T, Uehara T, Jodai S (1991) Combinations of wood and silicate. 1. Impregnation by water glass and applications of aluminium sulfate and calcium chloride as reactants. Mokuzai Gakkaishi 37:462-472

Furuno T, Shimada K, Uehara T, Jodai S (1992) Combinations of wood and silicate. 2. Wood-mineral composites using water glass and reactance of barium chloride, boric acid, and borax and their properties. Mokuzai Gakkaishi 38:448-457 
Furuno T, Uehara T, Jodai S (1993) Combinations of wood and silicate. 3. Some properties of woodmineral composites using the water glass-boron compound system. Mokuzai Gakkaishi 39:561-570

Ghosh SC, Militz H, Mai C (2008) Decay resistance of treated wood with functionalised commercial silicones. Bioresources 3:1303-1314

Ghosh SC, Militz H, Mai C (2009) The efficacy of commercial silicones against blue stain and mould fungi in wood. Eur J Wood Prod 67:159-167

Grace JK (2003) Termite resistant wood products. Sociobiology 41:123-129

Hadi YS, Westin M, Rasyid E (2005) Resistance of furfurylated wood to termite attack. Forest Prod J 55:85-88

Hill CAS (2006) Wood modification: chemical, thermal and other processes. John Wiley and Sons Ltd, England

Horng SB, Chu YI (1990) Development and reproduction of Asian corn borer (Ostrinia furnacalis Guenee) fed on artificial diet containing silica. Chin J Entomol 10:325-335

Howick CD, Creffield JW (1983) A rapid field bioassay technique with subterranean termites. Document IRG/WP 1188. International Research Group on Wood Preservation, Stockholm

Imamura Y, Nishimoto K (1986) Resistance of acetylated wood to attack by subterranean termites. Wood Res Kyoto 72:37-44

Kartal SN, Hwang W-J, Yamamoto A, Tanaka M, Matsumura K, Imamura Y (2007) Wood modification with a commercial silicon emulsion: effects on boron release and decay and termite resistance. Int Biodeterior Biodegrad 60:189-196

Lenz M, Runko S (1994) Protection of buildings, other structures and material in ground contact from attack by subterranean termites (Isoptera) with a physical barrier, a fine mesh of high grade stainless steel. Sociobiology 24:1-16

Mai C, Militz H (2004) Modification of wood with silicon compounds. Inorganic silicon compounds and sol-gel systems: a review. Wood Sci Technol 37:339-348

Matejuk JJ, Urbanik E, Pernak J (2004) New bis-quaternary ammonium and bis-imidazolium chloride wood preservatives. Holzforschung 58:292-299

Matthes R, Nehring HO, Dellith W (2002) Wasserglas-Holzschutz im Holzbau. In: Integrierter Umweltschutz im Bereich der Holzwirtschaft, 22-24 January 2002, Göttingen, Germany

Militz H, Schaffert S, Peters BC, Fitzgerald CJ (2008) Termite resistance of DMDHEU-treated wood. Document IRG/WP 08-40401. International Research Group on Wood Preservation, Stockholm

Moore D (1984) The role of silica in protecting Italian ryegrass (Lolium multiflorum) from attack by dipterous stem-boring larvae (Oscinella frit and other related species). Ann Appl Biol 104:161-166

Pernak J, Zabielska-Matejuk J, Urbanik E (1998) New quaternary ammonium chlorides-wood preservatives. Holzforschung 52:249-254

Pernak J, Zabielska-Matejuk J, Kropacz A, Foksowicz-Flaczyk J (2004) Ionic liquids in wood preservation. Holzforschung 58:286-291

Peters BC, Fitzgerald CJ (2004) Field exposure of Pinus heartwoods to subterranean termite damage. Aust For 67:75-81

Peters BC, Lenz M, Creffield JW (2006) Re-sealing cut ends of envelope-treated softwood framing timber to protect against damage by the Australian subterranean termite Coptotermes acinaciformis: a revisitation. Document IRG/WP 06-20335. International Research Group on Wood Preservation, Stockholm, Sweden

Preston AF, Kaig PA, Walcheski PJ (1986) Termite resistance of treated wood in an above ground field test. Document IRG/WP 1300. International Research Group on Wood Preservation, Stockholm, Sweden

Preston AF, Walcheski PJ, McKaig PA, Nicholas DD (1987) Recent research on alkylammonium compounds in the US. In: Proceedings, American Wood Preservers' Association (AWPA), vol 83, pp 331-334

Römpp CD (1995) CD-Römpp Chemie Lexikon. In: Falbe J, Regitz M (eds), 9th edn. Georg Thieme, Stuttgart, Germany

Su N-Y, Tamashiro M, Yates JR, Haverty MI (1982) Effect of behavior on the evaluation of insecticides for prevention of or remedial control of the Formosan subterranean termite. J Econ Entomol 75:188-193

Tamashiro M, Yates JR, Ebesu RH, Yamamoto RT (1987) The Formosan termite: Hawaii's most damaging insect. Hawaii Architect 16:12-14

Tamashiro M, Yates JR, Yamamoto RT, Ebesu RH (1991) Tunneling behaviour of the Formosan subterranean termite and basalt barriers. Sociobiology 19:163-170 
Tayabi K, Azizi P (1984) Influence of silica on rice yield and stem-borer (Chilo supremain) in Rasht/Iran in 1979-1989. Pesticides 18:20-22

Urbanik E, Zabielska-Matejuk J, Skrzypczak A, Pernak J (1997) Antifungal properties of new imidazolium chlorides against Coniophora puteana (Schum.:Fr.) Karst., Trametes versicolor (L.:Fr.) Pilát and Chaetomium globosum (Kunze:Fr.). Mater Org 31:247-263

van Iterson G (1933) The significance of the anatomy of wood for the preservation of marine structures against the shipworm (Teredo). In: Proceedings of the 5th Pacific Scientific Congress, Canada

Weigenand O, Militz H, Tingaut P, Sèbe G, de Jeso B, Mai C (2007) Penetration of amino-silicone microand macro-emulsions into Scots pine sapwood and the effect on water related properties. Holzforschung 61:51-59

Weigenand O, Humar M, Daniel G, Militz H, Mai C (2008) Decay resistance of wood treated with aminosilicone compounds. Holzforschung 62:112-118

Westin M, Rapp AO, Nilsson T (2004) Durability of pine modified by 9 different methods. IRG/WP 04-40288. International Research Group on Wood Protection, Stockholm, Sweden

Woodrow RJ, Grace JK (2008) Termite control from the perspective of the termite: a 21 st century approach. In: Schultz TP, Militz H, Freeman MH, Goodell B, Nicholas DD (eds) Development of commercial wood preservatives: efficacy, environmental and health issues. ACS symposium series 982. American Chemical Society, Oxford University Press, USA

Yamaguchi H (2003) Silicic acid: boric acid complexes as wood preservatives: ability of treated wood to resist termites and combustion. Wood Sci Technol 37:287-297 